\title{
THE COURSE OF PHARNAKES II'S PONTIC AND BOSPORAN CAMPAIGNS IN 48/47 B.C.
}

\section{Altay CoşKun}

\author{
I. INTRODUCTION
}

\begin{abstract}
A Roman CIVIL WAR HAD BROKen OUT in 49 B.C., Pharnakes II (63-47 B.C.) tried to regain the Pontic territories in Asia Minor. These would have been his by inheritance, had they not fallen under direct or indirect Roman domination in the course of the Third Mithradatic War (73-63 в.c.). While Caesar was fighting in Alexandria (48/47 в.c.), Pharnakes defeated the Roman legions under Cn. Domitius Calvinus at Nikopolis. The proconsul had the support of two kings: Deiotaros, who was in control of the Tolistobogian and Trokmian tetrarchies of Galatia, but had lost his Eastern-Pontic and MicroArmenian territories to Pharnakes, and Ariobarzanes III, who was the ruler of Kappadokia, but had been deprived of the northern parts of his realm by the Bosporan intruder. Despite this initial success, Pharnakes suffered a heavy defeat at Zela at the hands of Caesar, who reported to Rome in telegram style with his famous words veni, vidi, vici. ${ }^{1}$ The king retreated to Sinope, whence he shipped back to the Bosporos. In the meantime, his former deputy Asandros had revolted against him. Although Pharnakes was able to take back Theodosia and Pantikapaion, he was killed in combat shortly thereafter. ${ }^{2}$

Many thanks go to my friends Luis Ballesteros Pastor, Germain Payen, and Michał Halamus for helpful feedback on earlier drafts and also for excerpting Russian scholarship for me. Moreover, I would like to express my gratitude to the University of Waterloo, which funded my project Ethnic Identities and Diplomatic Affiliations of the Bosporan Kingdom with a UW/SSHRC Seed Grant in 2015/2016, and to the Social Sciences and Humanities Research Council of Canada (SSHRC) for granting substantial funds for the same project over the years 2017-2022. Information on the progress of the project is shared at http://www.altaycoskun.com.

Ancient sources have been adapted from the Perseus Collection (http://www.perseus.tufts. edu/hopper/collection?collection=Perseus:collection:Greco-Roman); tr. of Cassius Dio from Lacus Curtius (https://penelope.uchicago.edu/Thayer/E/Roman/home.html). Appian: Teubner ed. by L. Mendelson (Leipzig 1879; collated with ed. Budé by Goukowsky [2003]); translation from Loeb ed. by H. White (New York 1899; collated with new Loeb ed. by B. McGing [2019]). Cassius Dio: Loeb ed. by E. Cary and H. B. Foster (London 1914; text collated with Teubner ed. by U. P. Boissevain, Berlin, vol. 2 [1898]). Strabo: Loeb ed. by H. L. Jones (Cambridge 1924; collated with Groningen ed. by S. Radt [Göttingen 2002-2011] and tr. by Roller [2014]).

${ }^{1}$ Suet. Caes. 37; Plut. Caes. 50.2. Cf. Magie 1950: 1266, n. 27; Marek 2003: 40.

${ }^{2}$ For scholarly accounts focusing on Caesar, see, for example, Judeich 1885; Gelzer 1960; Jehne 1987; Freber 1993; Dobesch 1996; on Asia Minor in general, see, for example, Magie 1950; Hoben 1969; Mitchell 1993: 36; Saprykin 1996: 297-299; Marek 1993; 2003; 2010: 364-365, 376-378. For treatments of the Bosporan Kingdom, see especially Gajdukevič 1971: 322-325; also Saprykin 2002: 54-72; Yailenko 2010; for numismatic studies, see Leschhorn 1993: 44-46 and Nawotka
\end{abstract}


In a series of recent studies, I have tried to establish the chronology for the main events that unfolded along the Black Sea coast: the attack launched by Pharnakes, the revolt of Asandros, the major combats that took place in the former Pontic Kingdom of Asia Minor, and the Bosporan campaigns first of Pharnakes and then of Mithradates. ${ }^{3}$ The only date that is firmly attested in our sources is the Battle of Zela, which was fought on 2 August 47 в.c., or 21 May, if adjusted to the fully solar calendar as introduced by Julius Caesar in $46 / 45$ в.c. ${ }^{4}$ Key to my reconstruction is the observation that Pharnakes started his Pontic campaign only after hearing of the outcome of the Battle of Pharsalos. This was fought between the Caesarians and the Pompeians on 9 August 48 в.c. (7 June according to the Julian calendar), and it would have taken several days for the news to reach Pantikapaion. The fact that Calvinus withdrew his legions from Nikopolis to avoid the seasonal snowfall in the mountains of Armenia Minor points to a time around later December (ca early to mid-October Julian) 48 в.c. Accordingly, Pharnakes had roughly four months for his campaign from the Bosporos to Nikopolis. ${ }^{5}$

Despite his victory against Calvinus, Pharnakes refrained from expanding further into Kappadokia or Galatia, but concentrated on solidifying his grip on the former Pontic Kingdom. Upon hearing of the coup of Asandros, he set his army in motion, but had to turn back when Caesar showed up unexpectedly. After his crushing defeat at Zela on 2 August 47 в.c. (21 May Julian), Pharnakes fled to Sinope, whence he launched an attack on Pantikapaion. Decisive for the further chronology is that Caesar learnt of Pharnakes' death during his stay in Nikaia a month later, while he was reorganizing Roman Asia Minor and appointing Mithradates of Pergamon king. Accordingly, Pharnakes must have died towards the end of August, or no later than the first days of September, because Caesar reached Tarentum in Southern Italy as early as 24 September 47 в.с. (pre-Julian). ${ }^{6}$ If these dates are accurate (which I think they are), they

1991-92. For dynastic or biographical approaches, also see Sullivan 1990: 156-160 as well as the entries in Coşkun 2007-2019 on the individuals mentioned above.

${ }^{3}$ Coşkun 2019b; also see Coşkun 2007; 2018a; 2018b; 2019a; forthcoming.

${ }^{4}$ The Roman calendar had fallen behind the solar year by about two and a half months in 47 в.c.; see Groebe 1906: 814-817; cf. Judeich 1885; Gelzer 1960: 220-241; 267-268; Bennett 2004: 174; Coşkun 2007: 106-110, 159-174.

${ }^{5}$ The date has been transmitted in the Fasti Amiterni; see CIL I ${ }^{2}$ p. 244; cf. Gelzer 1960: 240 with n. 316. Many scholars allow for an invasion of Asia Minor in 49 в.c. or early 48 в.c. irrespective of Pharsalos; see, for example, Hoben 1969: 17-18; Freber 1993: 81, n. 388. Others accept the battle as the terminus a quo; see, for example, Gelzer 1960: 235; von Bredow 2018. Pharsalos as a terminus post quem is indeed required by B Alex. 69 and Cass. Dio 42.47.3; see Coşkun 2019b. Goukowsky (2003: 253, n. 1109) vaguely speaks of a "synchronism" for the Roman civil war and the Pontic campaign; he specifies this with the command of Calvinus and Caesar's Egyptian affair, but ultimately leaves all the relevant questions open. Mitchell (1993: 36) refers to App. Civ. 2.87-88 for the rumour that Pompeians had invited Pharnakes' invasion after Pharsalos, but military support for Pompey and an attack on his allies should not be conflated.

${ }^{6}$ See below, 104, n. 56. 
imply a very dense sequence of events prior to the Battle of Nikopolis and even more so after the Battle of Zela.

Based on this chronological framework, the present article seeks to offer a more detailed reconstruction and strategic interpretation of Pharnakes' Pontic and Bosporan campaigns. Many observations will be relevant for Roman imperial presence in the eastern Black Sea and the history of the Mithradatic dynasty, but these will be explored only as far as they matter for the stated aim. I shall go somewhat further with my discussion of the literary sources, whose understanding will determine the course of my argument.

\section{APPIAN'S REPORT OF THE PONTIC AND BOSPORAN CAMPAIGNS OF PHARNAKES}

There is barely any documentary evidence for Pharnakes' campaigns, whereas the literary tradition is broader than for most others of the later Hellenistic kings. ${ }^{7}$ This is due to the fact that we have the detailed eyewitness account of the pro-Caesarian Bellum Alexandrinum, which has a strong focus on the Battles of Nikopolis (34-41) and Zela $(65,69-76)$, and includes the preceding negotiations that mixed strategic considerations with propaganda of both sides. The account ends with the introduction of Mithradates of Pergamon (78), whom Caesar appointed king of the Bosporos after the murder of Pharnakes. Quite revealing of the Romano-centric perspective of the work is the fact that this final chapter of the book does not even mention the name of the usurper Asandros.

The other surviving historiographical accounts are much patchier. Strabo once presented a detailed narrative in his lost Historika Hypomnemata, as did Livy in the perished books of his Ab Urbe Condita. Of these, only pale reflections remain, scattered in some notes of the former's Geography and in the Periochae of the latter's work. ${ }^{8}$ The now-lost world history of Pompeius Trogus (Historiae Pbilippicae) also showed a strong interest in the Mithradatic dynasty, as the surviving Prologi (basically a list of chapter titles) as well as the Epitome Historiarum Philippicarum by the orator (not the historiographer) Justin reveal. A thin but useful version of this Hellenistic-Roman historiographical tradition is finally reflected in Cassius Dio's Roman Histories. ${ }^{9}$

\footnotetext{
${ }^{7}$ Numismatic evidence is particularly prominent in the discussions of Mithradatic and Bosporan history; see especially de Callatay 1997 for the Mithradatic material; for the Bosporus, see, for example, Anokhin 1986; Nawotka 1991-92; Frolova 1997; MacDonald 2005; Coşkun 2019a and 2019b. However, the coinage presently known does not seem to contribute anything of substance to the present question. Nor do we have any relevant inscriptions or archaeological finds that can directly be linked to Pharnakes' final campaigns.

${ }^{8}$ For Strab. Geogr. 11.2.17 (498C), see below, 99-100, n. 39. Liv. Per. 102 treated the campaign of Calvinus parallel to Caesar's war in Alexandria; Liv. Per. 103 dealt with the Battle of Zela after revolts in Africa and Spain.

${ }^{9}$ Cass. Dio 42.45-47, on which see below, especially section vi (99-102).
} 
Every modern reconstruction of Pharnakes' Pontic and Bosporan campaigns depends to a large degree on the short account provided by Appian in the mid-second century A.D. Luis Ballesteros has put forward strong arguments for the view that Appian's Mithridatic Book, while drawing on a rich Greek and Latin tradition, used Trogus as his main source. This is suggested not only on the basis of its comparison with the Prologi and the Epitome, but also in the light of various traces of Pontic or anti-Roman materials. ${ }^{10}$ But since Trogus' (pro-)Pontic source has not yet been identified, it is worthwhile recalling that Strabo of Amaseia himself hailed from the Pontic aristocracy, and was a younger contemporary of Pharnakes II and a friend of Queen Pythodoris. The latter ruled Pontos (ca 14/8 B.C.-ca A.D. 33) for much of the time that Strabo was composing his two major works in Rome under Augustus and early in the reign of Tiberius. ${ }^{11}$

Appian's Mithridatic Book has preserved several details we do not see elsewhere. The report has not yet received the attention it deserves, and will therefore be the focus of the present discussion. A translation may run as follows (Mith. 120.590-595):

(590) Pharnakes besieged the Phanagoreians and the towns neighbouring the Bosporos until the former were compelled by hunger to come out and fight, when he overcame them in battle; yet he did them no other harm, but made friends with them, took hostages, and withdrew. (591) Not long afterwards, he took Sinope and had a mind to take Amisos also, for which reason he made war against Calvi<n>us, the Roman commander, at the time when Pompey and Caesar were contending against each other, until Asandros, an enemy of his own, drew him away from Asia, while the Romans were still preoccupied. (592) Afterwards, he fought with Caesar himself (when the latter had overthrown Pompey and returned from Egypt), near Mount Skotios, where his father had defeated the Romans under Triarius. (593) He was beaten and fled to Sinope with 1,000 cavalry. Caesar was too busy to follow him, but sent Domitius against him. He surrendered Sinope to Domitius, who agreed to let him go away with his cavalry. (594) He killed his horses, though his men were extremely dissatisfied at this, then took ships and fled to the Bosporos. Here he collected a force of Scythians

\footnotetext{
${ }^{10}$ See Ballesteros Pastor 2013a, esp. 13-20 on Trogus, Justin, and Appian. He points out convincingly that Justin focused on sections of Mithradatic history largely ignored or only glossed over by Appian. In addition, the brief account of Pharnakes in App. Mith. 120.590-595 (on which see below, esp. section II, 88-92) may be a good example for this, since this king is ignored by Justin (although the very brief Prologi do not mention him either). One may add political geography as an overarching criterion for the design embraced by all three authors. Also see the many observations of Asheri (1998: 276-282) on the Mithridatika, mentioning Metrodoros of Skepsis as a proMithradatic author, but also reminding us that Trogus' uncle had served under Pompey in the East (the reference needs to be corrected to Just. Epit. 43.5.12).

${ }^{11}$ On Strabo and Pythodoris, see, for example, Strab. 12.3.33 [557C]; cf. 11.2.14, 18 [497C, 499C]; Braund 2005; Roller 2018a: 99-120, esp. 105-108. On the sources, see Lassère 1981, 12-35; Engels 1999: 86-88; Boshnakov 2003; Radt 2008: 252; Biffi 2010, 64-73; Gratsinskaya 2014: 128-130. On the biography, see Roller 2014: 1-27, with a genealogical table at x; cf. Radt 2008: 255; also Engels 1999, esp. 18-21.
} 
and Sarmatians and captured Theodosia and Pantikapaion. (595) His enemy Asandros attacked him again, and his men were defeated for want of horses, and because they were not accustomed to fighting on foot. Pharnakes alone fought valiantly until he died of his wounds, being then fifty years of age and having been king of the Bosporos for fifteen years. $^{12}$

Appian's view is overall pro-Roman, although it is more balanced than that of the Bellum Alexandrinum. His geographical and political focus is no longer limited to the immediate sphere of Roman affairs. While the narrative perspective is that of Rome's enemy Pharnakes, the author's partisanship for Rome is nevertheless apparent. First, the king is presented as the culprit, since he started a series of aggressions. He took Phanagoreia and Sinope, before the Romans were in a position to organize resistance, and he then moved on against Amisos due to his success over Calvinus. However, while the Bellum Alexandrinum repeatedly reproaches the king for cruelties against Pontic subjects and Roman citizens, Appian is willing to mention Pharnakes' mildness towards the defeated Phanagoreians, and also concedes him a heroic death in battle.

The king's representation in the Mitbridatic Book is, in fact, consistently ambivalent. First, when he is introduced as the instigator of the revolt against his father, Appian leaves open whether Pharnakes acted out of care for the kingdom or undue personal ambitions:

While this was the situation, Pharnakes, the son of whom he was most fond and whom he had often designated as the successor to his rule, either alarmed about the expedition and the kingdom (for he still had hopes of pardon from the Romans, but reckoned that he should lose everything completely if his father should invade Italy), or spurred by other motives, formed a conspiracy against his father. ${ }^{13}$

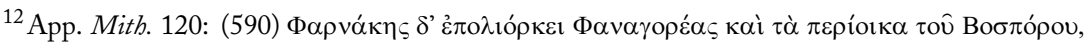

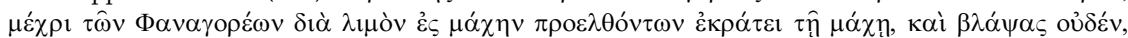

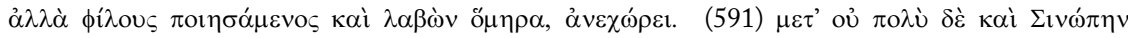

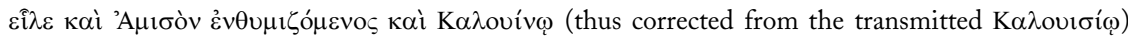

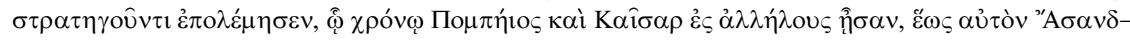

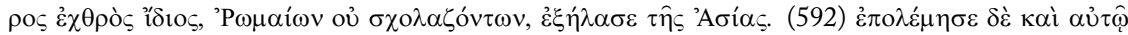

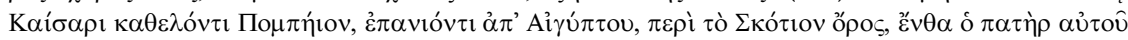
'P

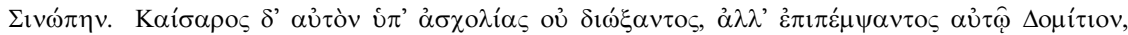

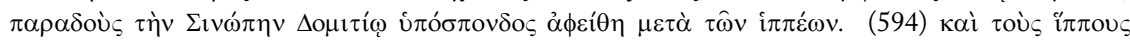

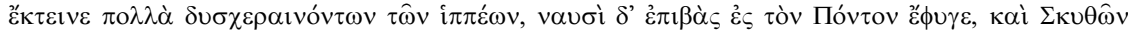

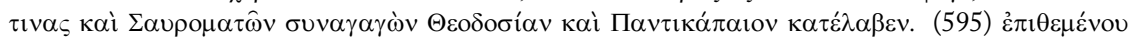

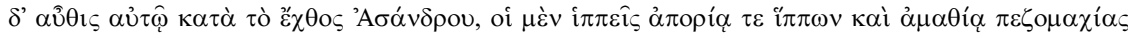

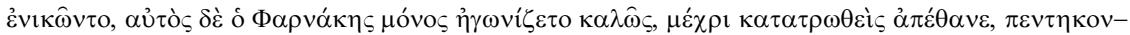

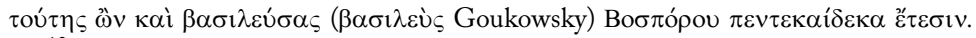

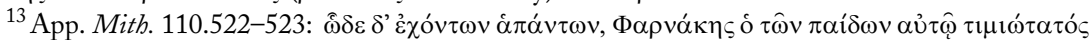

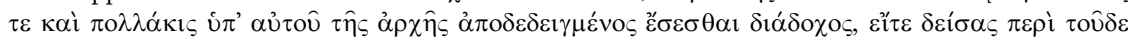

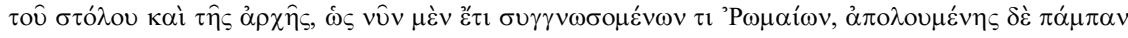

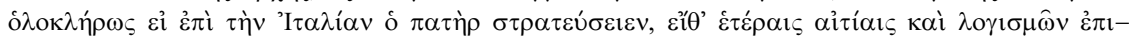

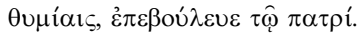


In this very section, the impression of Pharnakes' disloyalty towards his father may prevail, and appears consistent with Caesar calling him a $\pi \alpha \tau \rho \circ \kappa \tau o ́ v o \varsigma$ ("patricide") before launching the attack at Zela. But the broader context diminishes the love owed to this father, who had sold off his daughters to barbarians in return for military support and had killed many of his own kin-not to mention having, in his recklessness, squandered away his inherited kingdomand whose planned invasion of Italy was more designed to destroy whatever was left of his army than to reverse his fate. ${ }^{14}$ Pharnakes appears as a respectable leader during his insurrection, and not even the extradition of his father's corpse to Sinope is presented as impious, not least because Pompey granted Mithradates a royal funeral there. ${ }^{15}$ The whole episode ends with the positive conclusion that Pharnakes was acknowledged as a friend and ally of the Romans. His character is tainted only a few chapters later when Appian returns to Bosporan matters and reports the king's attack on Phanagoreia. ${ }^{16}$

Second, the Romans are presented as the defenders. In addition, Calvinus' defeat is at least indirectly excused by the circumstance that "Pompey and Caesar were contending against each other." ${ }^{" 17}$ The alleged synchrony is correct insofar as the Roman civil war was ongoing and had thus depleted Asia Minor of its regular legions and elite allied forces. The claim is, however, somewhat misleading, since the Pompeians had been defeated months before at Pharsalos, Pompey had been killed in Egypt, and Caesar himself had imprudently become embroiled in a dynastic war among the Ptolemies. The immediate connection of Pompey's defeat with Caesar's Alexandrian adventure ("when the latter had overthrown Pompey and returned from Egypt") reveals that the distortion is intentional. No less meaningful is, third, the reference to Triarius, as if Mount Skotios had been awaiting retaliation for twenty years. This detail loudly echoes Caesarian propaganda as established by the author of the Bellum Alexandrinum, for the sake of which the location of the historical battlefield of the Third Mithradatic War was moved south by a couple of miles. ${ }^{18}$

A fourth point of interest is the fate of the thousand horses on whose backs Pharnakes and his elite cavalry had escaped from Zela to Sinope. This incident recalls the hamstringing of the Seleukid elephants by the Roman ambassador Cn. Octavius in 162 B.c., which triggered the assassination of Octavius by a

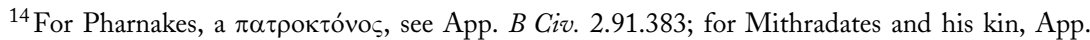
Mith. 64.266, 82.368-369, 108.516, 109.517, 110.130, 112.548; for Mithradates and his kingdom, App. Mith. 109.517, 520-521.

${ }^{15}$ See App. Mith. 113 on the immediate aftermath of Mithradates' death.

${ }^{16}$ See App. Syr. $110.522-113.555$ on the revolt and 120.590 on Phanagoreia (as quoted above, 89-90, n. 12).

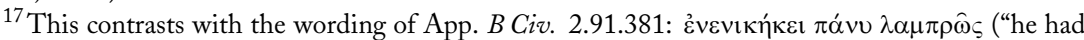
won an entirely splendid victory"), although this positive assessment is immediately undermined by the ensuing arrogance and cruelty.

${ }^{18}$ B Alex. 72-73 with Ballesteros Pastor 2012b: 3-4, referencing, among others, Olshausen and Biller 1984. 
certain Leptines of Laodikeia. ${ }^{19}$ Appian expresses equally strong disapproval of the Apamean and Sinopean slaughter, but it is noteworthy that, in the latter case, it is the king's own men who voice their extreme dissatisfaction. The deed is aggravated by the fact that Calvinus is said to have offered safe withdrawal to Pharnakes and his cavalry. Not much later, Asandros' victory is explained twice as the result of this ill decision, namely "for want of horses, and because they were not accustomed to fighting on foot." Obviously, Pharnakes is ultimately disqualified as a ruler in ethical terms and for his lack of leadership qualities, despite his previous achievements and final display of vigour. But how plausible is it that he destroyed his elite cavalry after negotiating his safe withdrawal seemingly with success? Also surprising is the understanding that the loss of the one thousand horses was decisive for the Bosporan war. Although this is not in itself implausible, Appian reveals that Pharnakes was able to recruit Scythians and Sarmatians before retaking Theodosia and Pantikapaion. The tight chronology set out above implies that the cities either went over to the legitimate king upon his arrival or that his renewed forces were so formidable that the cities shunned the perils of a siege. Either way, after Pharnakes had gained access to the resources of these two cities (and possibly more), ${ }^{20}$ his reinforcements must have balanced out most of the losses he had recently suffered in Pontos. To blame his later failure on a poor decision made in Sinope is therefore unconvincing.

If we had parallel accounts of Pharnakes' final Bosporan campaign, we might be in a position to simply reject some of Appian's claims. Given the situation as it is, I suggest accepting his factual details but not being bound to the "soft" information entailed in his narrative's causality or ideological messages. This caution will have some impact on the reconstruction of both Pharnakes' Pontic and Bosporan campaigns.

\section{PHARNAKES' SIEGE OF PHANAGOREIA}

Scholars are divided over the siege of Phanagoreia. Some regard this (§ 590) as the opening of Pharnakes' Pontic campaign during the Roman civil war, while others disconnect the events from each other. ${ }^{21}$ As the second royal residence of the kingdom, Phanagoreia had played a crucial role in the revolt against Mithradates vi Eupator, and thus also the succession of Pharnakes II in 63 в.c. The leader of the insurrection, a certain Kastor, had been rewarded with the

\footnotetext{
${ }^{19}$ App. Syr. 46.239-47.243. The most recent discussion is Sekunda 2019.

${ }^{20}$ There is no reason to believe that Chersonesos or Phanagoreia had supported Asandros so far, and possibly, he had not even extended his control to any place on the Taman peninsula. The loyalty of Phanagoreia to Pharnakes seems to be implied in Appian's account; for the role of Chersonesos in the 40s в.C., see Coşkun 2019a.

${ }^{21}$ See Ballesteros Pastor 1996: 278-279; Mielczarek 1999: 70-71; Abramzon and Kuznetsov 2011; Coşkun 2014.
} 
rank of an amicus populi Romani by Pompey, and possibly also with autonomous rule over Phanagoreia. ${ }^{22}$

We are somewhat in the dark regarding the city's fate between the last two wars that the Mithradatic kings fought against the Romans. A look at the tight sequence of events after Pharsalos excludes the possibility that Pharnakes could afford the time to besiege Phanagoreia when launching his Pontic campaign. Perhaps his attack on the city was an immediate response to the outbreak of the Roman civil war in 49 в.c., but the chronological indication "not long thereafter" (i.e., after the end of Mithradates vi) is sufficiently vague as to permit a date in the mid- or late-50s as well. Victor Gajdukevič surmises a connection with the rise of Burebista. The latter's conquest of Mesambria or even his destruction of Olbia, which Gajdukevič dates around 50 в.c., did not trigger any immediate response from the Senate. On the one hand, this may have signalled to Pharnakes that the Romans were no longer interested in the northern Black Sea region; on the other, it may have encouraged him to strengthen his own position, since the value of his alliance with Rome was doubtful anyway. While possible, the argument hinges on additional uncertainties regarding the chronology of Burebista's attacks on the Greek cities. ${ }^{23}$

Another option would be the mid-50s: this is when Pharnakes made conquests on the Taman Peninsula and assumed the title "Great King of Kings," which Michaela Stein-Kramer and Richard Sullivan have regarded as explicit defiance of Rome. ${ }^{24}$ Following this line of argument with an approximate date of 55/50 в.C., Sergey Saprykin further points to the growing tensions between Pompey and Caesar, which weakened any intimidating force the empire might have had. It would be more adequate, however, to evoke the failed Parthian campaign of Crassus and the destabilization of all eastern frontier areas as of

${ }^{22}$ See App. Mith. 108.505-511, 113.555, 114.560-561; Oros. 6.5.2; Suda s.v. Kastor.

${ }^{23}$ Gajdukevič (1971: 324) dates the siege of Phanagoreia to ca 50 в.с. Hoben (1969: 12-14 and 15-16) is undecided as to how much before the Pontic campaign Phanagoreia was besieged, as is MacDonald (2005: 45). In Coşkun 2014: 135, I opted for the early part of the Roman civil war. Von Bredow (2018), in turn, dates the conquest of Phanagoreia after Pharsalos, as the other attacks. Olbrycht (2001: 437) speaks of "um 48 v.Chr." (despite his reference to Gajdukevič). Note that Abramzon and Kuznetsov (2011: 70) leave the time open, but relate the destruction of the city to the revolt around 63 в.c. Ruscu (2018, with ample bibliography) is undecided as to whether Burebista conquered the Greek cities before or after 60 в.c.; cf. Freber 1993: 167; Dobesch 1994; and Roller 2018b: 357.

${ }^{24}$ Sullivan (1990: 156) is followed by Ballesteros Pastor (2017: 297, 300-301). On the numismatic evidence, also see Leschhorn 1993: 45 and MacDonald 2005: 45-46. The latter suggests that the assumption of the new title was a reaction to the death of the King of Kings Tigranes of Armenia. Stein-Kramer (1988: 60) even proposes an earlier date (without specifying it), because the strategic location of Phanagoreia made its subjection a prerequisite for Pharnakes' conquest of the Scythians on the Asian border of the Maiotis; this may be the reason that Veh and Brodersen (1987: 475, nn. 590-591) date the city's conquest to 61 в.C. 
53 в.с., as the rivalry between Pompey and Caesar turned into open hostility only in 50 в.с. ${ }^{25}$

Our sources provide us with clear indications that Pharnakes was indeed much more cautious until as late as the Battle of Pharsalos in 48 в.C., as has been mentioned above. At any rate, Appian not only seems to be disconnecting the king's Phanagoreian and Pontic campaigns from each other, but also sees no need to explain Roman inactivity. He synchronizes the conflict between Pompey and Caesar only with Pharnakes' initial success in his Pontic campaign, not with the fate of Phanagoreia. Given that only Kastor, and not the whole city, had been an amicuspopuli Romani, there does not appear to have been a strong moral obligation to stage a Roman intervention against Pharnakes - at least in the literary construction of Appian. In addition, the recognition of both Pharnakes and Kastor in 63 в.C. was the result of historical contingency, but could not be a sustainable solution, given that Phanagoreia was entirely enclosed by territory and waterways controlled by the Bosporan kingdom. Hostile relations might have been in the short-term interests of those who had started the revolt against the Mithradatic dynasty, but certainly were against the long-term economic development of the city. Pharnakes' leniency following the siege probably took mutual economic interests into account. As a result, his takeover of the city happened soon after the death of Kastor some time in the 50s B.c. and did not have any immediate bearing on his Pontic campaign.

\section{THE BEGINNING OF PHARNAKES' PONTIC CAMPAIGN}

Further in want of clarification is the itinerary of Pharnakes' Pontic campaign. Appian conveys the impression that it began with the takeover of Sinope, and continued with the victory over Calvinus at Nikopolis and the capture of Amisos; next came the king's defeat at the hands of Caesar near Zela (§ 592-593) and his retreat to Sinope, which he finally surrendered to Calvinus before sailing back to the European parts of the Bosporan kingdom (§ 593-595). Had we no other evidence to draw on, we would be inclined to believe that his Pontic campaign had been inaugurated by an attack on the former royal residence from the sea and that Pharnakes had therefore entrusted his whole army to his fleet. ${ }^{26}$ If this were the case, however, one wonders why there were not enough ships to receive one thousand men with their horses. This would have

\footnotetext{
${ }^{25}$ Saprykin 2002: 34. On the campaign of Crassus and Caesar's conflict with Pompey, see, for example, Gelzer 1960: 134-140, 157-177.

${ }^{26}$ This is implied, for example, by Gelzer (1960: 235) and Yailenko (2010: 225-226). The same impression is conveyed for the delivery of Eupator's corpse, which was taken by ship from Pantikapaion to Sinope (App. Mith. 113.552). Strabo is of no help here. While he does not mention how Sinope got into Pharnakes' possession, concerning the conquest of Amisos he states (12.3.14

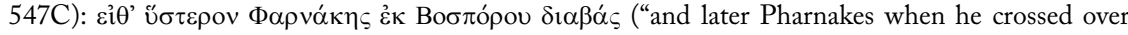
from the Bosporos"). Since we know, however, that this happened after the Battle of Nikopolis and included the city's siege from land and sea, the information is quite worthless for our concern.
} 
been only a fraction of his former cavalry, not to mention his infantry. We do not have any other numbers, but to match the allied Roman-Anatolian forces under Calvinus, Deiotaros, and Ariobarzanes, one can easily surmise an army of 20,000 or more. These figures do not take into consideration the garrisons he might have left behind in maritime Pontos when confronting the allied army at Nikopolis. Admittedly, we need not expect that the entire Bosporan fleet had remained in Sinope. A significant part may then have been stationed in Amisos, Pharnakeia, or Trapezus. But even ten per cent of his original fleet should have been sufficient to transport one thousand men plus their horses and supplies. This calculation does not even take into account that further private vessels must have been available locally.

As a result, we should not expect that there was a royal fleet harboured in Sinope at the time. But we may even go further and surmise that the major part of the Bosporan army had arrived in Asia Minor by land, after marching across the Taman peninsula, through Kolchis and Armenia Minor. A small fleet is still likely to have flanked and perhaps also supplied the train along the coast, since Pharnakes was eager to reach the former Mithradatic possessions as quickly as possible, in order not to lose momentum. But nothing suggests that any significant part of that fleet, whatever its size, was stationed in Sinope.

\section{THE SEQUENCE OF PHARNAKES' CONQUESTS ACCORDING TO THE BELLUMALEXANDRINUM}

A land route for the Pontic campaign is, in fact, implied in the Bellum Alexandrinum, for it specifies that Pharnakes headed south from Armenia Minor into Kappadokia in an early phase of the war. This direction is obvious from the complaints voiced by Deiotaros. It is hard to say whether the attack of Ariobarzanes' kingdom had been part of the initial plan or was seen as a convenient opportunity during the campaign. At any rate, the diplomatic intervention of Calvinus induced Pharnakes to return to Armenia Minor. It is telling that the proconsul did not mention in his negotiations with the king, at least according to the Bellum Alexandrinum, that the cities of Sinope, Amisos, and Amaseia, which formed part of the province Pontus et Bithynia, were not included in the complaints. Indeed, Calvinus had soldiers conscripted even in Ponto. This seems to confirm that Sinope was still under Roman control, at least when the proconsul dispatched his emissionaries to recruit in Cilicia and Pontus-Bithynia (B Alex. 34). A few weeks later, when Calvinus arrived in Komana Pontike and resumed his negotiations with Pharnakes, he was obviously still of the belief that the invader was only holding Armenia Minor (B Alex. 35). Consistent with this, the Bellum Alexandrinum reports that it was the victory of Nikopolis that encouraged the king to occupy Pontus as well (B Alex. 41). ${ }^{27}$

\footnotetext{
${ }^{27}$ On the battle and its strategic consequences, also see Saprykin 2002: 45-46.
} 
Less certain is whether Pharnakes had already occupied the Eastern Pontic domain of Deiotaros, including Trapezus and Pharnakeia. This region is not singled out as contested either. I see two possible explanations for this silence. Pharnakes might have chosen an inland route from Kolchis, marching south along the bank of the lower Akampsis and crossing mountain passes to reach the lower Euphrates; following this river, he could have encircled the eastern and southern borders of Armenia Minor before arriving in the northern part of the kingdom of Kappadokia. Or, more likely, Deiotaros' complaint of having lost Armeniam minorem, regnum suum ( $§ 34$ ) included his possessions on the Pontic coast. The latter seems to be more convincing, not only for the strategic advantages that the coastal route offered Pharnakes, but also for its consistency with the wording of the rest of the Bellum Alexandrinum and of Cassius Dio's report, which will be addressed below (section vi, 99-102).

In a different context, Ballesteros Pastor (2012a and 2016) explains that the part of the Mithradatic kingdom located east of the Halys had previously been called Armenia, since the Mithradatids called the two core territories of their Anatolian realm Pontus and Armenia, following Achaemenid geopolitical terminology and rivalling Kappadokian claims to the territory east of the Halys. This view is largely convincing, even though it does not fully match the evidence. ${ }^{28}$ At any rate, the toponyms Armenia Minor and Mikroarmenia are attested only after the reorganization of the East under Pompey. We cannot disprove that they were not older, but the Bellum Alexandrinum reflects that terminology was still in flux during the 40s B.c. It is therefore most probable that Pharnakes' soldiers followed the coastline until Trapezus and Pharnakeia, which allowed for the safest and swiftest progress.

How far westwards did his train move? There was barely enough time to march all the way to Sinope (especially since we know that Amisos resisted him), then turn back south-east to reach at least the northern parts of Kappadokia, only to withdraw towards Nikopolis by the fall of 48 в.с. The most convenient way inland would have been to follow the Iris Valley, which merged into the Black Sea between Themiskyra and Amisos. This path provided smooth access to the Lykos Valley. Magnopolis, Amaseia, and Zela would have been on

\footnotetext{
${ }^{28}$ Ballesteros Pastor draws on Schmitt (1972), who identified the epigraphically attested Tayaiy

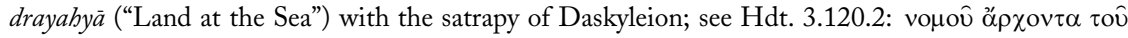

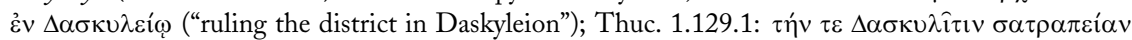
("and the satrapy Daskylitis"). The city of Daskyleion was located on the Asian coast of the Propontis. The Mithradatic dynasty began its rule in Bithynian Kios before establishing itself in Paphlagonian Kimiata; see Diod. Sic. 19.40.2; Strab. 12.3.41 (562C); cf. Marek 2010: 296-297; Ballesteros Pastor 2013b: 185-186. Less certain is, however, whether or not Eutr. 5.5, Oros. 6.2.1 (cf. 5.10.2), and Polyb. 25.2.3, 11-12 reflect this Persian subdivision, pace Coşkun 2016: 851-852; cf. Strab. 12.3.28 (555C). Note that Ballesteros Pastor (2010) was yet undecided whether rex Ponti was a creation of Pharnakes I after the conquest of Sinope (also see below, 108, n. 64) or a choice of Mithradates vi as a title that reflected his rule over all his subjects around the Black Sea.
} 
his way along the Upper Lykos before reaching the Kappadokian kingdom of Ariobarzanes. ${ }^{29}$

Admittedly, those three cities formed part of the province Pontus et Bitbynia, which is not explicitly mentioned as having been invaded by Pharnakes in the Bellum Alexandrinum. But they were still located in Armenia as defined by Ballesteros Pastor: the former Mithradatic territory east of the Halys. Nevertheless, it is perhaps preferable to surmise a slightly more limited understanding of Armenia (Minor) by the author of the Bellum Alexandrinum, since he not only attributes Sinope to Pontus, but also Amisos, which was situated between the mouths of the Halys in the west and the Iris in the east. At least in the coastal area, the Iris functioned as the natural boundary between Pontus-Bithynia and the "Armenian" kingdom of Deiotaros. But the recent geopolitical terminology was not yet applied further to the south: the Lykos Valley still appears to be subsumed under Armenia, although Pompey had incorporated Magnopolis and even Nikopolis into the province Pontus-Bithynia. Accordingly, Calvinus demanded the evacuation of Armenia in his first diplomatic exchange with Pharnakes (B Alex. 34) ${ }^{30}$

The fact that the first major combat would take place so far to the east of the Iris reveals that Pharnakes adjusted his strategy after learning that the Romans continued claiming the control of Asia Minor in its entirety. As long as he thought that Calvinus had three full Roman legions with him, alongside fresh recruits and Anatolian allies, he preferred to avoid a military encounter and hoped to achieve more through negotiation than through fighting, and thus withdrew from Kappadokia somewhere to the north. ${ }^{31}$ His decision to turn east may have been induced by the news that Calvinus himself was coming from Pontus. ${ }^{32}$ Nikopolis seemed to offer a safe refuge, especially since Calvinus might have hesitated to follow him there later in the fall. This would have gained Pharnakes time and also allowed for the subjection of the highlands of Armenia Minor. The Bellum Alexandrinum singles out Komana (Pontike) as the gathering place for all the Roman contingents and their allies. Calvinus followed his enemy and was looking for a quick decision, which led to his

${ }^{29}$ For a discussion of the cities of Pontus-Bithynia as established by Pompey, see Marek 1993.

${ }^{30}$ Cf. Cass. Dio 42.47.1, who even locates Zela in Armenia. Note, however, that Caesar's terminology, as reported in $B$ Alex. 70, is not an exact match, since he distinguishes between the province (Pontus) and the territory of the allies. On Pompey's organization of Pontus-Bithynia, see below, 101, n. 49.

${ }^{31} B$ Alex. 35 reports that he first intended to withdraw further, but slowed down his retreat upon hearing that Calvinus had sent two of his three legions away to Caesar.

${ }^{32}$ See B Alex. 35. This route endorses my previous observation that his complaints were about Armenia and not yet Pontus, from which he received recruits while marching along the coast. Differently, Judeich (1885: 64-65) assumes that Calvinus marched from Lydia through central Anatolia; slightly modifying this reconstruction, I suggested a similar itinerary with a starting point in Ephesos; see Coşkun 2007: 167-168. 
own defeat and retreat, the latter dated before the first snowfall by Cassius Dio (42.46.2-3).

Should we therefore discard Appian's information that Sinope was taken before the Battle of Nikopolis? With the exception of those who think that the invasion had started with the conquest of Sinope by sea, the capture of the Greek cities on the coast is largely dated to the time after Nikopolis. ${ }^{33}$ This reconstruction is in line with the account of the Bellum Alexandrinum, according to which Pharnakes occupied Pontus after Nikopolis (B Alex. 41). But regardless of this compatibility, it is not a necessary conclusion. We might well think that the takeover of Sinope was an achievement of the Bosporan fleet. I assume that Pharnakes' navy was patrolling the north-eastern coast of Asia Minor as far west as the mouth of the Iris, to secure the king's supply line, after he had turned south. But after Calvinus had passed by, there would have been a good opportunity to sail westwards, demanding that all coastal cities and tribes submit to the "legitimate" king Pharnakes. The fact that all of the available Roman soldiers had just been called away by the proconsul to confront the main force of the invader certainly lowered Sinope's potential to resist. At the same time, Roman rule over Asia Minor must have appeared quite insecure: not only had Pompey's defeat at Pharsalos resulted in the slaughter of the best provincial and allied forces from Asia Minor, but Calvinus had just dispatched two of his three legions to Egypt after hearing of Pharnakes' invasion (B Alex. 34). The situation did thus inspire hope that relief could be expected soon, if the harbour were closed to the Bosporan fleet. Many inhabitants of the former capital of the Pontic kingdom were certainly quite willing to return to Mithradatic rule, to get rid of Roman tax collectors and military settlers, and to prevent the Romans who were then fighting under Calvinus from returning. ${ }^{34}$

The Amiseni, however, chose to resist the king, and additional pressure from Pharnakes' land forces was needed after the Battle of Nikopolis to compel them to surrender. Most probably, the cruelties against the Pontics that our sources speak of were largely limited to the punishment of the Amiseni, the only Greek victims singled out in our accounts. This reconstruction would also explain why Caesar would later pardon those who had suffered for their

\footnotetext{
${ }^{33}$ Magie (1950: 409) and Gajdukevič (1971: 324) date the capture of Amisos and Sinope after Nikopolis, and this is also the implication of Lassère (1981: 76, n. 3). So does Gelzer (1960: 235), although this conflicts with his assumption that Pharnakes had previously landed on the north coast of Asia Minor, which seems to imply the swift takeover of Sinope at the beginning of his campaign. Saprykin (2002: 45-46) also emphasizes that only Amisos resisted, but leaves open the question of how Sinope was conquered. Elsewhere Saprykin (1996: 298-299) speaks of a general defiance of the Greek cities (in contrast to the country), which is only exemplified by Amisos. Mitchell (1993: 36-37) assumes that Sinope resisted as determinedly as Amisos did.

${ }^{34}$ The special devotion of the Sinopeans to the Mithradatic dynasty appears to be implied in their staunch resistance to Lucullus and in their hosting of the royal tombs (App. Mith. 83.370 and 113.551-553).
} 
loyalty to Rome, whereas he would punish Sinope severely, establishing military settlers in its confines and founding the Colonia Iulia Felix Sinopensis. ${ }^{35}$ Against this background, Strabo's qualified silence gives further support to the view that Sinope opened its harbour to Pharnakes' fleet without any noteworthy resistance. He reports that the city was conquered twice, once by Pharnakes I and next by Lucullus, ending his account with the recent settlement of a Roman colony $(12.3 .11[546 \mathrm{C}])$. It is unlikely that Strabo would have left a third conquest by Pharnakes II unmentioned.

\section{PHARNAKES' CONQUESTS ACCORDING TO CASSIUS DIO}

We are now well prepared to read Cassius Dio's version of Pharnakes' campaign. His Roman Histories are notorious for their many inaccuracies, which are not absent from his narrative of the Pontic campaign either. ${ }^{36}$ But the brief summary of the early part of the king's itinerary seems to capture his route and the extent of his conquests quite well, regardless of some textual problems. A traditional rendering of the relevant sentence (which is normally regarded as slightly corrupt) and its translation run as follows (Cass. Dio 42.45.3):

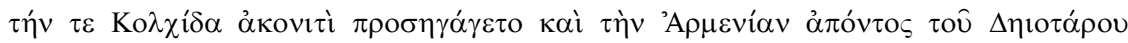

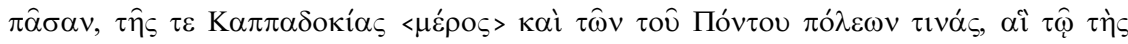

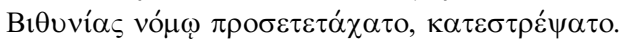

He got possession of Kolchis without any difficulty, and in the absence of Deiotaros subjugated all of Armenia, and <part> of Kappadokia, and some cities of Pontos that had been assigned to the district of Bithynia. ${ }^{37}$

Apparently, Cassius Dio confirms the view that Pharnakes' conquests had begun with Kolchis, which neighboured his kingdom to the south-east and had enjoyed amicitia with Rome since the reorganization of the East under Pompey in ca 63 в.c. ${ }^{38}$ Pharnakes' presence there is confirmed by Strabo, who, however, only mentions him plundering the sanctuary of Leukothea, without hinting at the timing or strategic context. Traditionally, the Leukotheion was claimed either for Vani or the Borjomi area, both in inland Georgia, but Strabo's description actually requires us to look for a site along the coast, perhaps on the Green

\footnotetext{
${ }^{35}$ See Magie 1950: 414 for the comparison; for the colony, also see, in different contexts, Levick 1967: 5, 84 and Mitchell 1993: 36-37. For Amisos suffering cruelties by Pharnakes, see App. B Civ. 2.91.381; Cass. Dio 42.46; B Alex. 41 and 70, however, only vaguely speaks of in Ponto; for the reward of freedom, see Strab. 12.3.14 (547C). Also see Ballesteros Pastor 2013b: 189 and forthcoming for more details.

${ }^{36}$ For instance, he has Caesar send Domitius Calvinus against Pharnakes from Egypt (Cass. Dio 42.46.1).

${ }^{37}$ Cf. Sullivan 1980: 1144; Coşkun 2007: 161, n. 148.

${ }^{38}$ See App. Mith. 114.560 and Eutr. 6.14 .1 on 64 B.c.; also Hoben 1969: 70; Freber 1993: 81-82.
} 
Cape of Batumi, so that it was in easy reach for the king when he sailed by on his Pontic campaign. ${ }^{39}$ Wolfgang Hoben (1969: 17-18) dates the invasion of Kolchis to 49 B.C., and thus about a year earlier than the Battle of Pharsalos. ${ }^{40}$ Ballesteros Pastor (2017: 300) goes as far back as ca 55 в.c., disconnecting this invasion from Pharnakes' Pontic campaign, just as he does with the conquest of Phanagoreia. But both views ignore that the Kolchians' friendly ties with Rome had remained intact, since they supported their benefactor Pompey at Pharsalos. ${ }^{41}$ Accordingly, Pharnakes could easily march through their territory due to the absence of their main forces in 48 в.c. This is precisely what Cassius

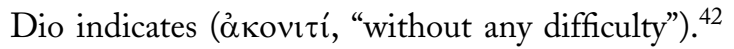

Next, the historiographer seems to be mentioning "Armenia in its entirety"

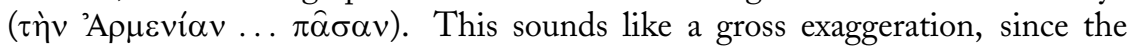
major kingdom of Armenia east of the Euphrates was certainly not affected by his campaign. ${ }^{43}$ We can, however, avoid such a distortion easily, if we inter-

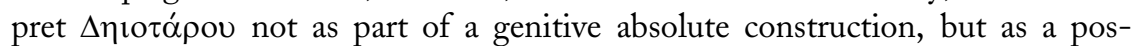
sessive genitive. Cassius Dio is then talking of the conquest of "all of Armenia that belonged to Deiotaros, while he was absent" (namely at Pharsalos). ${ }^{44}$ The author is thus using an alternative expression for Armenia Minor, the loss of which Deiotaros had indeed reported to Calvinus according to the Bellum Alexandrinum (34.1, 67.1). This terminology is analogous to Cassius Dio's "Armenia of Tigranes," which denotes the major Armenian Kingdom east of the Euphrates in a different context $(36.45 .3,36.48 .2) .{ }^{45}$ Having shown that a geographically sound interpretation can be regarded as consistent with Cassius Dio's terminology, I would not go as far as insisting that he fully grasped the geographical implications of his statement. Perhaps he found $\pi \rho 0 \sigma \eta \gamma \alpha \dot{\alpha} \gamma \varepsilon \tau$...

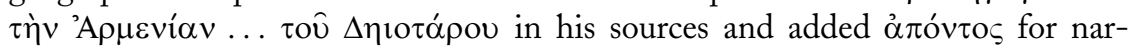

${ }^{39}$ Strab. 11.2.17 (498C); see Coşkun forthcoming b. Vani is located about $75 \mathrm{~km}$ up the Phasis; see Lordkipanidze 1996: 251-269; cf. Radt 2008: 255. The Borjomi area is further east in the Moschian Mountains; see Braund 1994: 146-151, 185; cf. Roller 2018b: 641; Braund 2000b: 1260.

${ }^{40}$ Hoben is followed by Sullivan (1990: 156), who even considers 50 в.с.; similarly, see Saprykin 2002: 40 (50/49 в.с.) and 1996: 297 (long before Pharsalos).

${ }^{41}$ See Cic. Att. 9.9 .2 = $176 \mathrm{ShB}$ on 48 в.c.; cf. App. Civ. 2.211; cf. Yoshimura 1961: 483. Freber (1993: 81, n. 388) believes that Aristarchos, the appointee of Pompey, was still alive when Pharnakes invaded Kolchis in 49/48 в.c.; cf. Stein-Kramer 1988: 60-64; Lordkipanize 1996: 292-295. But he had probably been dead since 53 в.C.; see Coşkun 2018c.

${ }^{42}$ Without these arguments, the conquest of Kolchis is normally explained as the beginning of Pharnakes' Pontic campaign; see, for example, Magie 1950: 408-409; Stein-Kramer 1988: 61; von Bredow 2018. Saprykin (2002: 45-46) explains the speedy conquests in Asia Minor of 48/47 B.c. by reference to the civil war. That the reconstruction does not imply chronological difficulties is also supported by the fact that Herodotus (1.104.1) speaks of a thirty-day march from the Maiotis to the river Phasis.

${ }^{43}$ See Yoshimura 1961: 483; Prantl 2018 on King Artavasdes II.

${ }^{44}$ For Armenia Minor as part of Deiotaros' kingdom, see Strab. 12.3 .13 (547C); Cic. Div. 2.79; and see below, see Coşkun forthcoming c.

${ }^{45}$ See also Cass. Dio 36.9.1; cf. Ballesteros Pastor 2016: 278. 
ratological and $\pi \hat{\alpha} \sigma \alpha v$ for stylistic reasons. ${ }^{46}$ Either way, it is safe to assume that Deiotaros' eastern territory was regarded as a unity, whether it was named Deiotaros' Armenia or Armenia Minor. ${ }^{47}$ All of this was lost with the arrival of Pharnakes.

Cassius Dio's reference to Kappadokia has caused further problems. While the Bellum Alexandrinum confirms that Pharnakes progressed into the kingdom of Ariobarzanes, the narrow timeframe does not allow for more than the occupation of its northern stretches (BAlex. 34-35). ${ }^{48}$ To solve the problem, scholars have previously conjectured that a word such as $\mu \varepsilon \varepsilon_{\rho} \varsigma \varsigma$ has slipped from the text in the course of the transmission. This is quite possible, since the paratactic

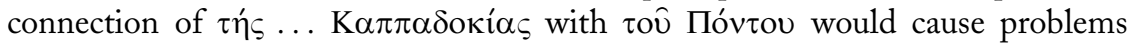
otherwise: $\tau \hat{\omega} v \ldots \pi$. . $\lambda_{\varepsilon} \varepsilon v$ is enclosing its partitive genitive complement $\tau o \hat{u}$

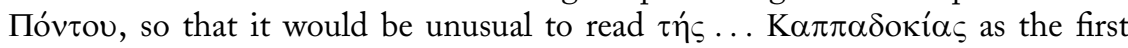
genitive compliment of $\tau \hat{\omega} v$. . . ó$^{\prime} \lambda \varepsilon \omega v$. In addition, $\tau \hat{\omega} v \ldots \pi$. . partitive genitive ruled by $\tau \iota v \alpha$ s $\varsigma$ and is further defined by the relative clause $\alpha i$

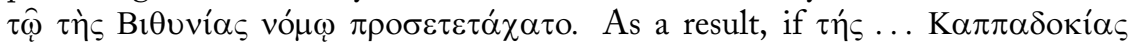

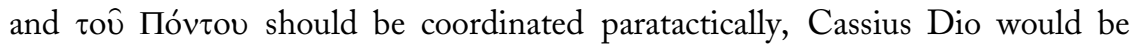
speaking of "some of the cities of Kappadokia and Pontos that had been assigned to the district of Bithynia." But Pompey did not include any cities of Ariobarzanes' kingdom in the province of Bithynia (which was renamed Pontus et Bithynia). ${ }^{49}$

Political geography is, however, less of a problem, if the newly founded poleis of the Lykos Valley are viewed as belonging to Pontus-Bithynia politically, but to Kappadokia geographically. Strabo, for instance, still used the expression "Kappadokia on the Pontos." ${ }^{\text {D }}$ And as far as grammar is concerned, the transmitted text could also be read as adding two pairs: Kolchis and Deiotaros' Armenia were overrun in their entirety, whereas in Kappadokia and Pontos only some

\footnotetext{
${ }^{46} \mathrm{~A}$ limited geographical understanding would also be implied in the remaining part of the sentence, if it were regarded as complete.

${ }^{47}$ The unity of this territory is also assumed by Sullivan (1980: 1144), according to whom Caesar passed it on to Ariobarzanes III after his victory at Zela. But Cassius Dio (41.63.3) makes it clear that the territory was shared between Ariobarzanes and Deiotaros. This is in accordance with $B$ Alex. 66.5, which says partem Armeniae Minoris, although this forms part of a supplement; but see Coşkun forthcoming $\mathrm{c}$ for a discussion and a map that updates Coşkun 2008: map 3. Also note that the kings of Kappadokia had a historical claim on the land east of the Halys, parts of which had been conquered or acquired by Mithradatic kings from the third to the late second or early first centuries; see Ballesteros Pastor 2016: 278 with further references.

${ }^{48}$ Von Bredow (2018) speaks of "Colchis, Cappadocia, Armenia Minor (see Armenia) and parts of Pontus," but we should not read too much into such a brief, encyclopaedic list.

${ }^{49}$ See Strab. 12.3.1-2 (541C), 12.3.9 (544C), with Marek 1993; cf. Marek 2003: 36-43.

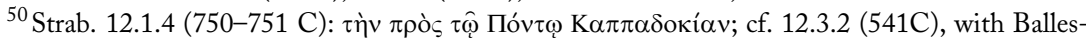
teros Pastor 2016: 274-276, 280; also Ballesteros Pastor 2013b: 183-185, 189. For further termi-

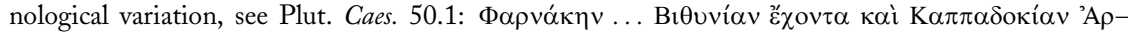

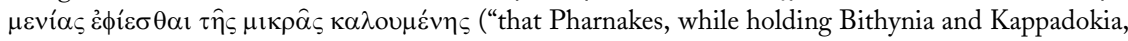
attacked so-called Minor Armenia").
} 
cities were affected (namely those that belonged to the Roman province at the time). Stylistically, $\tau \iota v \alpha$ $\varsigma$ would be a good contrast to $\pi \hat{\alpha} \sigma \alpha v$, both standing in an emphatic end position. The only remaining shortcoming would be $\tau \hat{\omega} v$, since it should actually have started the second pair, if the cities of Kappadokia were to be included. At all events, the suggested addition of $\mu \varepsilon \varepsilon_{\rho} \rho \varsigma$ to the transmitted text seems to yield the smoother solution, but whether it ultimately captures Cassius Dio's idiosyncrasies and vague geographical knowledge remains an open question.

Nevertheless, Cassius Dio largely confirms the sequence of Pharnakes' conquests as presented in the Bellum Alexandrinum. Both accounts are further compatible with the version of Appian, as long as we do not assume that the latter's report was aiming at completeness. He does not mention Kolchis, Pharnakeia, Trapezus, or Kappadokia, perhaps because Pharnakes did not meet with any resistance in these cities, or was even welcomed. At any rate, these areas were emptied of their elite forces due to the Roman civil war, so it would have been futile to oppose a fully-fledged royal army, especially when it enjoyed the support of a fleet. Our awareness of the hardship of the Amisenoi is due to the fact that it was the only city of the former Pontic kingdom ready to deny the invader admission. It paid a high price for this choice. ${ }^{51}$

\section{AFTER NIKOPOLIS}

With his victory at Nikopolis, Pharnakes consolidated all his gains in Pontic Armenia. Aiming for the former Mithradatic possessions west of the Iris (and Halys) in Paphlagonian Pontos would be the next step, for a variety of reasons. First of all, winter was approaching, and it was safer for him and the major part of his army to return to the Black Sea coast before snowfall blocked the mountain passes. Second, he would make best use of his time and resources by laying siege to Amisos during winter, when long marches were not an option anyway. Third, a personal appearance in the former royal residence of Sinope, which seems to have submitted to his might without much pressure, would have important symbolic meaning. He could showcase his royal munificence here, to serve as a contrast to his treatment of restive Amisos. Whether indeed he felt emboldened to strike out for the cities of Western Asia Minor, as his father had endeavoured in the First and Third Mithradatic Wars and as Cassius Dio purports he did, we cannot say, because Asandros thwarted his plans (Cass. Dio 42.46.2-42.47.1).

We have no information about his precise itinerary or the deployment of his army. Not even the brief mention of his response to Asandros' usurpation reveals his whereabouts (Cass. Dio 42.47.1). ${ }^{52}$ They only confirm that he im-

${ }^{51}$ See above, 98-99, with n. 35 on Amisos.

${ }^{52}$ Less detailed is App. Mith. 120.591, quoted above, 89-90, n. 12. 
mediately set in motion his forces. This was around April (Julian) 47 в.c. ${ }^{53}$ The location from where they started remains uncertain: that their core had been concentrated at Sinope or Amisos is as likely an assumption as a more even distribution along the coast from Sinope to Trapezus. Likewise we cannot say how far he and his troops made it towards the Bosporos. Regarding his fleet, he may have split it up to support various units on their way, or part of it may have been sent ahead to prepare for a swift march of the infantry. The only thing we can say for sure is that Pharnakes' fleet was not awaiting him in Sinope, where he arrived most unexpectedly a few days after his defeat by Caesar.

That the major confrontation took place at Zela has some further strategic implications. The location reflects the king's effort to shield his newly acquired kingdom from the dictator. Apparently he had no intention of leaving Asia Minor undefended in order to maximize his chances of withstanding Asandros; rather, he was confident that he could take on both of his opponents. While a negotiated peace with Caesar was clearly his preference, he needed to be prepared for a military confrontation with him as well.

\section{THE END OF THE PONTIC CAMPAIGN IN SINOPE}

The negotiations before the Battle of Zela and the course of the combat on 21 May (Julian) are known in considerable detail thanks to the Bellum Alexandrinum, which is complemented by the summary version of Cassius Dio. That Pharnakes fled with 1,000 horsemen to Sinope is also well established thanks to Appian. After my discussion of the campaign, however, the direction of the flight appears in a somewhat different light. The more direct way north to Amisos or Temiskyra seems to have been blocked or at least threatened by his enemies, so, just for the sake of survival, he chose a way that would separate him even further from whatever was left of his navy and soldiers along the coast. Afraid of Calvinus, he even took the most desperate measure of killing the horses and setting sail with his remaining 1,000 men. This line of events has been teased out from the testimony of Appian above in section II (88-92).

There is, however, a tension in Appian's account which puts into question my previous conclusion, since Appian seems to attest negotiations between Calvinus and Pharnakes. These are said to have resulted in the surrender of Sinope in return for the safe withdrawal of the king with his 1,000 cavalrymen. The latter tradition gains support through a passing comment in Cassius Dio's account, which implies that Pharnakes re-established friendship with Rome through the proconsul. The context is the reorganization of Asia Minor in Nikaia, which was being finalized when news of Pharnakes' death reached Caesar:

\footnotetext{
${ }^{53}$ See above, 87, nn. $4-6$ on the chronology.
} 
To Mithradates the Pergamene he gave a tetrarchy in Galatia and the title of king and allowed him to wage war against Asandros, so that by conquering him, he

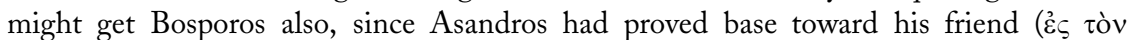
$\phi i ́ \lambda$ ov). ${ }^{54}$

For a long time, the text was understood as being critical of Asandros, because he had betrayed his own "friend" Pharnakes. But Heinz Heinen (1994: 75-77) pointed out that the causality of this passage only becomes clear if we understand that the victim Pharnakes had been Caesar's "friend." Heinen was not able to specify how exactly friendship may have been re-established after Zela, but he suggests that Calvinus negotiated a deal with him, which was approved by Caesar in Nikaia. ${ }^{55}$ While Appian supports the view that Calvinus parleyed with Pharnakes, the reconstruction is ultimately impossible for chronological reasons, given that Caesar appointed Mithradates as successor to Pharnakes in Nikaia early in September $\left(B\right.$ Alex. 78) ${ }^{56}$ A formal conclusion of friendship with Caesar through the agency of Calvinus is thus not feasible, unless Caesar instructed Calvinus to conclude friendship with Pharnakes still at Zela.

There are further difficulties. It may be less relevant that Appian's Mithridatic Book does not single out friendship as a result of negotiations. More challenging is the implication of his narrative that the negotiations were aborted. That Pharnakes felt sufficiently desperate to slaughter the 1,000 horses seems to suggest ongoing hostility, rather than friendship, with the Romans. Perhaps he was afraid that the horses, if left alive, could be used to imperil his navigation along the coast. There was probably not even enough time to supply the ships adequately for the longer trip to the Bosporos, so that they would soon have to find safe harbours in north-eastern Asia Minor or Kolchis. That Appian twice speaks of "flight" further reduces the likelihood of a friendly settlement

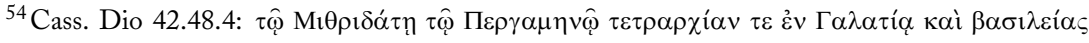

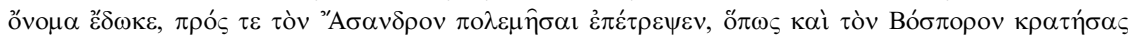

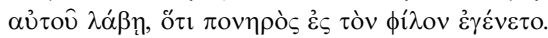

${ }^{55}$ Cf. Heinen 1996: 85; Dobesch 1996: 66; Ballesteros Pastor 2018a. Saprykin (2002: 50-52) also accepts that Caesar re-established friendship with Pharnakes, hoping to gain him as an ally in his planned wars against the Parthians and Dacians- but neither war was then a pressing concern for Caesar, nor could he plausibly expect Pharnakes to remain loyal. Stein-Kramer (1988: 66) does not explain how the friendship bond established by Pompey might have continued despite the king's invasion of Asia Minor.

${ }^{56}$ See also Heinen 1994; Ballesteros Pastor 2018b. App. Mith. 121.596 and Cass. Dio 42.48 .4 remain without chronological indications. Gelzer (1960: 240-241) reports the appointment of Mithradates viI before Caesar reached Nikaia and leaves open whether Caesar knew of Pharnakes' death; cf. Magie 1950: 413-414. Caesar travelled by ship via Athens, Patrae, and Tarentum, where he arrived on 24 September according to a calculation based on various Ciceronian letters; cf. Broughton 1952: 286. Nawotka (1991-1992: 35) dates Mithradates' appointment to August 47 в.c.; Lordkipanidze (1996: 295) supposes that Mithradates was targeting Pharnakes in Kolchis; he even dates the death of Mithradates to 47 в.C., as does Engels (1999: 331); cf. Yailenko 2010: 226.
} 
with Calvinus. ${ }^{57}$ In addition, it should be of some weight that neither the Bellum Alexandrinum nor Cassius Dio's narrative of the aftermath of Zela gives any room to a potentially peaceful settlement. Both of them speak of flight as well, and thus agree with Appian in this regard, as does Plutarch in his Life of Caesar. ${ }^{58}$

We are left with two possible conclusions. Either the existence of friendship between Caesar and Pharnakes was simply made up in Nikaia, to add a specious justification for not simply acknowledging Asandros as amicus populi Romani instead of sending Mithradates against him, or Caesar had at least instructed Calvinus to offer Pharnakes peace, amicitia populi Romani, and amicitia Caesaris in return for a quick withdrawal from Asia Minor. The king might still have had significant troops garrisoned along the coast, which Caesar was not able to ascertain at the time; the Pontic war could thus have been protracted for a long time, while the ongoing Roman civil war required all available resources. Perhaps a combination of the two explanations yields the most likely solution: that Caesar indeed gave the plausible instruction to negotiate and possibly offer friendship, and that this intention was misrepresented as effective friendship later in Nikaia. Obviously, Pharnakes did not know about his "good luck" when he left from Sinope on confiscated ships. He was expecting no mercy from Caesar, and thus fled for his life.

\section{THE FINAL CHAPTER: PHARNAKES' BOSPORAN CAMPAIGN}

The preceding discussion has some ramifications for the revolt of Asandros. The scratch fleet that Pharnakes gathered in Sinope was not at all suited to sailing across the Black Sea in order to reclaim the Bosporan Kingdom. There is no way that he should have risked this endeavour with only 1,000 poorly equipped men. I have mentioned above the plausible expectation that a significant number of ships and infantry were either still waiting for him in the north-eastern corner of Asia Minor or moving northwards along the coast of Kolchis. Pharnakes' first goal should have been to reunite with these forces before confronting Asandros. None of our lacunose sources provides direct evidence for this explanation, but indirectly they do support such a course. Strabo's report of Pharnakes' pillaging the sanctuary of Leukothea would fit much better with the stressful situation he was in on his return to the Bosporos. When he had marched through Kolchis the year before, there was no significant resistance to him, and thus not much to be gained from inaugurating his royal rule with sacrilege. But in 47 в.C., refilling his war chest was essential for survival (Strab. 11.2.17 [498C]). ${ }^{59}$

${ }^{57}$ App. Mith. 120.593-594, quoted above, 89-90, n. 12. Cf. the shorter version of App. Civ. 2.92, which resembles Cass. Dio 42.47.5.

${ }^{58}$ B Alex. 77 and Cass. Dio 42.47; cf. Plut. Caes. 50.2; Eutr. 6.22.

${ }^{59}$ See above, 100 , n. 42 on the year 48 в.c. 
It is worthwhile repeating the few details that Appian reports for Pharnakes' return (Mith. 120.594): "then he took ships and fled to the Bosporos. Here he collected a force of Scythians and Sarmatians and captured Theodosia and Pantikapaion." "Scythians and Sarmatians" are ethnic labels that were often used quite vaguely, and Scythian fighters especially could be recruited nearly anywhere in the hinterlands along the northern shores of the Black Sea ${ }^{60}$ But the conditions under which Pharnakes had to act suggest that he was recruiting from among the neighbours of his Asiatic domains. The same seems to be implied in a reference by Strabo to the Aorsoi and Sirakoi: their territories are given as north and along the river Tanaïs for the former and south of it for the latter "when Pharnakes ruled the Bosporos."

Considering the narrow timeframe of four to five weeks between Zela (2 August = 21 May [Julian]) and Caesar's being told of his death (early in September [pre-Julian]), one cannot reasonably assume that Pharnakes had the leisure to send out ambassadors to summon allies or recruit mercenaries. I suggest, rather, that he had arranged for fresh troops to gather in a strategically convenient location immediately after receiving news of Asandros' revolt. He did not intend to return with his entire force from Pontos, but rather to leave behind as many troops as were necessary to defend his recent acquisitions against the Romans, Galatians, and Kappadokians combined. Messengers may have taken the sea route first, perhaps reaching Gorgippia in about a week or less, ${ }^{62}$ before continuing on horseback. This way, they could easily establish contact with his Scythian and Sarmatian allies in the course of May (pre-Julian). Their cavalry contingents may thus have been available near Phanagoreia as early as June.

The slim summary version of Appian reveals even more: if the first conquest of Pharnakes was Theodosia and the second Pantikapaion, the most likely scenario is that Asandros had been residing in Pantikapaion as the epitropos of the king, and that this was also the place where he started the revolt, proclaiming himself archōn. ${ }^{63}$ Either Asandros was unable to get hold of the Taman penin-

\footnotetext{
${ }^{60}$ Generally on Scythians and Sarmatians, see, for example, Rausch 2013: 35-43, 75-77; Mordvintseva 2013.

${ }^{61}$ Strabo (11.5.8 [506C]) specifies that King Spadines of the southern Aorsoi, whose territory is said to have expanded into the Caucasus (cf. 11.2.1 [492C]), commanded some 200,000 horse riders, and the other Aorsoi even more, whereas King Abeakos of the Sirakoi ruled over 20,000. The territories of these tribes and their historical significance has been much debated; cf. Gajdukevic 1971: 323-324; Stein-Kramer 1988: 60-61; Braund 2000a: 1204; Mielczarek 1999: 73, 80, n. 5. Olbrycht (2001: 436, 438) prefers to identify the Achardaios with the Kuban on the Taman peninsula and suggests that the Aorsoi and Sirakoi are the most likely allies for Pharnakes' Bosporan campaign in 47 B.C.

${ }^{62}$ Strabo (11.2.17 [498C]) surmises two or three days for sailing from the mouth of the Phasis to Amisos or Sinope.

${ }^{63}$ In contrast, Hoben (1969: 22 and 25) assumes that Asandros revolted on the Taman peninsula and controlled at least Phanagoreia, so that Pharnakes aimed for Pantikapaion first; he further believes that Asandros next invaded the European part and defeated the king a few days after his
} 
sula, or he might have been repulsed from there by forces loyal to Pharnakes. The dense sequence of events further implies that Asandros' following was not overly strong among the inhabitants of the major Greek cities. Pharnakes' quick success in Theodosia may have encouraged opposition against Asandros also in Pantikapaion. We cannot even say whether there was any major fighting at all before the king encountered the main body of Asandros' force, probably not too far from the capital. It was in this battle that Pharnakes lost his life at the end of August or in the first days of September 47 в.с.

\section{HISTORICAL CONCLUSIONS ON PHARNAKES' CAMPAIGNS}

Starting from a characterization of the Bellum Alexandrinum and the relevant chapter in Appian's Mithridatic Book (120.590-595), I have tried to reconstruct a more complete and plausible outline of Pharnakes' last military campaigns than has been offered in previous scholarship. He had sufficient time to gather, train, and equip his army before notice of Pompey's defeat at Pharsalos (9 August / 7 June [Julian] 48 в.с.) encouraged him to launch his attack. His troops, while flanked by his fleet, quickly marched through Kolchis and followed the coastline of Pontic Kappadokia as far Themiskyra. While he wished to eventually recover Amisos and Sinope, his ancestors' Pontic capital, he avoided attacking them, since they hosted Roman garrisons. Instead, he turned south, following the Iris Valley as far as the northern stretches of Kappadokia, even beyond the boundaries of former Pontos.

Following the diplomatic intervention of $\mathrm{Cn}$. Domitius Calvinus, he retreated from Ariobarzanes' territory, but began consolidating his control of Armenia Minor along the Lykos Valley. Those boundaries, he hoped, were easier to defend, both strategically and diplomatically. By fall 48 в.c., the two armies met near Nikopolis along the middle course of the Lykos. It was there that the Romans, together with their Galatian and Kappadokian allies, suffered a heavy defeat. Their withdrawal opened for Pharnakes the way back to the Iris Valley and thus to the major Greek cities in the north. Sinope might well have taken his side with little or no resistance to his fleet, whereas Amisos was besieged, conquered, and harshly punished by the king.

Negotiations with the Romans were resumed when Caesar returned from Egypt in the subsequent spring. But diplomacy was only dilatory, and Pharnakes' forces were crushed near Zela on 2 August / 21 May (Julian) 47 в.c. He barely escaped with 1,000 horsemen to Sinope. The route of his flight reflects the desperate situation he was in, because he did not have a substantial garrison or fleet stationed in the city, which he had deemed loyal to him. It appears that the only way he could escape was west; otherwise he would have been able to reach the Black Sea coast near Themiskyra and reunite with parts of his fleet

arrival; cf. MacDonald 2005: 45. But if so, there would have been no need for Pharnakes to

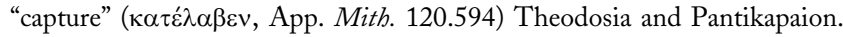


and some garrisons he had left in the area. Once beyond the Iris, he could have reached Amisos, but seems to have been too afraid of the citizens who had suffered so much at his hands. Sinope was in safe reach, but barely equipped to support his safe withdrawal. The available ships were just enough for his thousand men, but not for their horses, which had to die.

Pharnakes' losses were tremendous, but his sacrifices were well calculated, since he could recruit other troops on the way; he probably picked up some of his ships and garrisons stationed along the Pontic coast, and large contingents of the Aorsoi and Sirakoi awaited him somewhere in the north-west of the Taman Peninsula. With these forces, he set over to the Crimea to confront the usurper Asandros. There is no firm explanation why he was able to take Theodosia and Pantikapaion before being destroyed by his enemy in the ensuing battle. One possibility is that his army was still much weaker than that of Asandros, but that he could still count on royalist supporters in Theodosia and Pantikapaion. An alternative option is that the violent conquests of one or two of the cities had exhausted or diminished his army, or perhaps turned many of his former subjects against him. We cannot know: the account of Dio is too slim to provide us with a rationale, and the artful conception of Appian obscures the strategic and political realities of Pharnakes' Bosporan campaign.

\section{HISTORIOGRAPHICAL CONCLUSIONS: PHARNAKES AND SINOPE IN APPIAN'S DESIGN}

If my conclusions are accepted, the strategic role of Sinope appears to be greatly overstated by Appian. He awards prominence to the city due to its former role as Pontic capital and the symbolic value it thus carried. Reference to Sinope allows him to shape the account of Pharnakes' Pontic campaign as a ring composition. The smooth acquisition of the city stands for the happy beginnings of his campaign. ${ }^{64}$ The conquest of Amisos on the one hand figures as the prize for his defeat of Calvinus, but on the other represents growing resistance to the king, while also illustrating his strength. Next comes the revolt of Asandros, which appears to be the turning point of his Pontic campaign as much as of his whole life. The insurrection is followed by his defeat at the hands of Caesar, before his desperate return to and flight from Sinope. These incidents vividly contrast with his proud arrival the year before.

In fact, the ring composition extends beyond the Pontic campaign. On the one side, the success of Pharnakes' Bosporan endeavours earlier in his rule is exemplified by the siege and conquest of Phanagoreia (120.590). On the other

\footnotetext{
${ }^{64}$ See above, 94, n. 26 and 98, n. 34 on Sinope. If the transmitted text is complete, Appian has missed the opportunity to craft yet another meaningful ring composition: the splendor of the Pontic kingdom only began with Pharnakes I's conquest of Sinope in the 180s B.c. (see Avram 2016), but Appian's archaiologia jumps from Mithradates I Ktistes to Mithradates v Euergetes (App. Mith. 9.28-10.30).
} 
side stands his final contest with Asandros (120.594b-595). Although Appian indicates his initial success at Theodosia and Pantikapaion, and also grants him a heroic death, Pharnakes' despair is nevertheless shown by his need to turn to Scythians and Sarmatians for assistance. While he had been able to overcome the hostility of Phanagoreia and thus gain the loyal support of Greek citizens earlier in his reign, at the end of his life he was depending on "barbarians." 65 His actions against the Phanagoreians are shown to be based on a combination of vigour and mildness in government, whereas the seemingly needless cruelty against the horses in Sinope is presented as the immediate reason for his final defeat by Asandros. Appian's account of Pharnakes' kingship has thus been shaped into a moral lesson: the lack of self-restraint as displayed against the Amisenoi and the horses at Sinope would lead-sooner rather than later-to disaster.

Department of Classical Studies

UNIVERSITY OF WATERLOO

200 University Avenue West

Waterloo, ON

N2L 3G1

acoskun@uwaterloo.ca

BIBLIOGRAPHY

Abramzon, M. and V. Kuznetsov. 2011. "The Phanagorian Revolt against Mithridates vi Eupator," in N. Povalahev and V. Kuznetsov (eds.), Phanagoreia und seine historische Umwelt. Von den Anfängen der griechischen Kolonisation (8. Jh. v.Chr.) bis zum Chasarenreich (10. Jh. n.Chr.) Altertümer Phanagoreias 2. Göttingen. 15-90.

Anokhin, V. A. 1986. Monetnoe delo Bospora (Coinage from the Bosporos). Kiev.

Asheri, D. 1998. "The Achaeans and the Heniochi: Reflections on the Origins and History of a Greek Rhetorical Topos," in R. Gocha (ed.), The Greek Colonisation of the Black Sea Area: Historical Interpretation of Archaeology. Stuttgart. 265-285.

Avram, A. 2016. "Sur la date du traité entre Pharnace et Chersonèse Taurique," in J.-Ch. Couvenhes (ed.), La symmachia comme pratique du droit international dans le monde grec. Besançon. 213-237.

Ballesteros Pastor, L. 1996. Mithrídates Eupátor, rey del Ponto. Granada.

— 2010. "Del reino Mitridátida al reino del Ponto: orígenes de un término geográfico y un concepto político," Orbis Terrarum 9: 3-10.

— 2012a. "Los herederos de Artabazo: La satrapía de Dascilio en la tradición de la dinastía Mitridática," Klio 94: 366-379.

- 2012b. "Some Aspects of Pharnaces II's Image in Ancient Literature." (This is the revised manuscript, which had first been published [in Russian] in Antiquitas Aeterna 1 [2005 (published in 2007)] 211-217.

2013a. Pompeyo Trogo, Justino y Mitrídates: Comento al Epitome de las Historias Filípicas $(37,1,6-38,8,1)$. Hildesheim.

${ }^{65}$ Obviously, this Graeco-Roman perspective ignores the realities of the Bosporan kingdom. 
2013b. "Nullis umquam nisi domesticis regibus: Cappadocia, Pontus and the Resistance to the Diadochi in Asia Minor," in V. Alonso Troncoso and E. M. Anson (eds.), After Alexander: The Time of the Diadochi (323-281 B.c.). Oxford. 183-198.

- 2016. "The Satrapy of Western Armenia in the Mithridatid Kingdom," in V. Cojocaru and A. Rubel (eds.), Mobility in Research on the Black Sea. (Iassi, July 5-10, 2015). Cluj-Napoca. 273-287.

— 2017. "Pharnakes II and the Title 'King of Kings', $A E W$ 16: 297-303.

2018a. "Pharnakes II, King of Pontos" (2008, revised 2018), in Coşkun 2007-2019, s.v.

2018b. "Mithradates (viI) of Pergamon, King of the Trokmoi, King Designate of Kolchis and the Bosporos" (2008, revised 2018), in Coşkun 2007-2019, s.v.

— forthcoming. "The Return of the King: Pharnakes II and the Persian Heritage," in A. Coşkun (ed.), Ethnic Constructs, Royal Dynasties and Historical Geography around the Black Sea Littoral. Stuttgart.

Bennett, C. 2004. "Two Notes on the Chronology of the Late Republic," ZPE 147: 169-174.

Biffi, N. 2010. Scampoli di Mithridatika nella Geografia di Strabone. Bari.

Boshnakov, K. 2003. Die Thraker südlich vom Balkan in den Geographika Strabos: Quellenkritische Untersuchungen. Wiesbaden.

Braund, D. 1994. Georgia in Antiquity: A History of Colchis and Transcaucasian Iberia, 550 B.C. - A.D. 562 . Oxford.

2000a. Map 84 Maeotis (1996), in Talbert 2000: 1201-12.

2000b. Map 88 Caucasia (1997), in Talbert 2000: 1255-67.

- 2005. "Polemo, Pythodoris and Strabo: Friends of Rome in the Black Sea Region," in A. Coşkun (ed.), Roms auswärtige Freunde in der späten Republik und im frühen Prinzipat. Göttingen. 253-270.

Broughton, T. R. S. 1952. The Magistrates of the Roman Republic 2. New York.

Coşkun, A. ed. 2007-2019. Amici Populi Romani: Prosopographie der auswärtigen Freunde Roms = Prosopography of the Foreign Friends of Rome. Trier 2007-2008; Waterloo 2010-2019 (Version 09: 2019). http://www.altaycoskun.com/apr.

— 2007. Von der 'Geißel Asiens' zu 'kaiserfrommen' Reichsbewohnern. Studien zur politischen und gesellschaftlichen Entwicklung der Galater unter besonderer Berücksichtigung der amicitia populi Romani und der göttlichen Verehrung des Augustus (3. Jh. v.-2. Jh. n. $C h r$.$) , unpublished habilitation thesis, University of Trier.$

- ed. 2008. Freundschaft und Gefolgschaft in den auswärtigen Beziehungen der Römer $(2$. Jh. v.Chr.-1.Jh. n.Chr.). Frankfurt.

— 2014. "Kastor von Phanagoreia, Präfekt des Mithradates und Freund der Römer," in N. Povalahev (ed.), Phanagoreia und darüber binaus ...-Festschrift für Vladimir Kuznetsov. Göttingen. 131-138.

— 2016. "Philologische, genealogische und politische Überlegungen zu Ardys und Mithradates, zwei Söhnen des Antiochos Megas (Liv. 33,19,9)," Latomus 75: 849-861.

2018a. "Addendum to Asandros" (2007, revised 2018), in Coşkun 2007-2019, s.v. 2018b. "Addendum to Dynamis" (2007, revised 2018), in Coşkun 2007-2019, s.v. 2018c. "Aristarchos, Dynast von Kolchis” (2007, revised 2018), in Coşkun 20072019 s.v. 
2019a. "Chersonesos Taurike and the Freedom (not yet) Granted by Rome-A New Interpretation of the Embassy of C. Julius Satyrus to Rome, 46 B.c. (IOSPE $\mathrm{I}^{2}$ 691)," in A. Bencivenni, A. Cristofori, F. Muccioli, and C. Salvaterra (eds.), PHILOBIBLOS-Scritti in onore di Giovanni Geraci. Milan. 281-306.

- 2019b. "The Date of the Revolt of Asandros and the Relations between the Bosporan Kingdom and Rome under Caesar,” in M. Nollé, P. M. Rothenhöfer, G. Schmied-Kowarzik, H. Schwarz, and H. Christoph von Mosch (eds.), Panegyrikoi Logoi: Festschrift für Johannes Nollé zum 65. Geburtstag. Bonn. 125-146.

— forthcoming a. "The Bosporan Kings in-between the Mithridatic Tradition and Friendship with Rome: The Usurpation of Asandros Revisited," in D. Braund, A. Chaniotis, and E. Petropoulos (eds.), Roman Pontos. Athens.

- forthcoming b. "Searching for the Sanctuary of Leukotheia in Kolchis," in A. Coşkun (ed.), Ethnic Constructs, Royal Dynasties and Historical Geography around the Black Sea Littoral. Stuttgart.

—_ forthcoming c. "Die Teilung 'Armeniens' durch Caesar und die Entstehung 'Kleinarmeniens', in Orbis Terrarum 18.

de Callatä̈, F. 1997. L'histoire des guerres mithridatiques vue par les monnaies. Louvain-laNeuve.

Dobesch, G. 1994. "Zur Datierung des Dakerkönigs Burebista,” in R. Göbl (ed.), Die Hexadrachmenprägung der Groß-Boier. Ablauf, Chronologie und historische Relevanz für Noricum und Nachbargebiete. Vienna. 51-68. 1996. "Caesar und Kleinasien," Tyche 11: 51-77.

Engels, J. 1999. Augusteische Oikumenegeographie und Universalbistorie im Werk Strabons von Amaseia. Stuttgart.

Freber, P.-S. G. 1993. Der hellenistische Osten und das Illyricum unter Caesar. Stuttgart.

Frolova, N. A. 1997. Monetnoe delo Bospora (seredina I v. do n.é.-seredina IV v. n.é.) (Coinage from the Bosporos (Mid-1st Century B.C. to Mid-4th Century A.D.) 1. Moscow.

Gajdukevič, V. F. 1971. Das Bosporanische Reich². Berlin.

Gelzer, M. 1960. Caesar: Der Politiker und Staatsmann ${ }^{6}$. Wiesbaden.

Goukowsky, P. 2003. Appien, Histoire Romaine 7: Livre XII: La Guerre de Mithridate2. Paris.

Gratsinskaya, L. I. 2014. "The Northern Black Sea Region in the Geography of Strabo," in Alexander V. Podossinov (ed.), The Periphery of the Classical World in Ancient Geography and Cartography. Leuven. 123-132.

Groebe, P. 1906. "Der römische Kalender in den Jahren 65-43 v. Chr.," in W. Drumann (ed.), Geschichte Roms in seinem Übergange von der republikanischen zur monarchischen Verfassung, oder: Pompeius, Caesar, Cicero und ihre Zeitgenossen nach Geschlechtern und mit genealogischen Tabellen ${ }^{2}$ 3. Berlin and Leipzig, repr. Hildesheim 1964. 755-827.

Heinen, H. 1994. "Mithradates von Pergamon und Caesars bosporanische Pläne. Zur Interpretation von Bellum Alexandrinum 78," in R. Günther and S. Rebenich (eds.), E fontibus haurire: Beiträge zur römischen Geschichte und zu ibren Hilfswissenschaften. Paderborn. 63-79.

— 1996. "Rome et le Bosphore: Notes épigraphiques," Cahiers du Centre Glotz 7: 81-101.

Hoben, W. 1969. Untersuchungen zur Stellung kleinasiatischer Dynasten in den Machtkämpfen der ausgehenden römischen Republik. Diss., Mainz. 
Jehne, M. 1987. Der Staat des Dictators Caesars. Cologne.

Judeich, W. 1885. Caesar im Orient: Kritische Übersicht der Ereignisse vom 9. August 48 bis October 47. Leipzig.

Lassère, F. 1981. Strabon, Géographie 9: Livre XII. Paris.

Leschhorn, W. 1993. Antike Ären: Zeitrechnung, Politik und Geschichte im Schwarzmeerraum und in Kleinasien nördlich des Tauros. Stuttgart.

Levick, B. 1967. Roman Colonies in Southern Asia Minor. Oxford.

Lordkipanidze, O. 1996. Das alte Georgien (Kolchis und Iberien) in Strabons Geographie. Neue Scholien. Tr. Nino Begiaschwili. Amsterdam.

MacDonald, D. 2005. An Introduction to the History and Coinage of the Kingdom of the Bosporus: Including the Coinage of Panticapaeum (with "Apollonia" and "Myrmecium"), Phanagoria, Gorgippia, Sindicus Limen or the Sindoi, Nymphaeum, Theodosia, and the Kings of the Cimmerian Bosporus. Lancaster.

Magie, D 1950. Roman Rule in Asia Minor to the End of the Third Century after Christ. 2 vols. Princeton. 1950.

Marek, C. 1993. Stadt, Ära und Territorium in Pontus-Bithynia und Nord-Galatia. Tübingen.

2003. Pontus et Bithynia: Die römischen Provinzen im Norden Kleinasiens. Mainz.

- 2010. Geschichte Kleinasiens in der Antike. Munich.

Mielczarek, M. 1999. The Army of the Bosporan Kingdom. Lódź.

Mitchell, S. 1993. Anatolia. Land, Men, and Gods in Asia Minor 1: The Celts in Anatolia and the Impact of Roman Rule. Oxford.

Mordvintseva, V. 2013. "The Sarmatians: The Creation of Archaeological Evidence," OJA 32: 203-219.

Nawotka, K. 1991-92. "Asander of the Bosporus: His Coinage and Chronology," AJN 3-4: 21-48, pls. 3-4.

Olbrycht, M. J. 2001. "Die Aorser, die Oberen Aorser und die Siraker bei Strabon. Zur Geschichte und Eigenart der Völker im nordostpontischen und nordkaukasischen Raum im 2.-1. Jh. v. Chr.," Klio 82: 425-450.

Olshausen, E. and J. Biller. 1984. Historisch-geographische Aspekte der Geschichte des Pontischen und Armenischen Reiches 1: TAVO B 29/1. Wiesbaden.

Prantl, H. 2018. “Artavasdes II., König von Armenien” (2008, revised 2018), in Coşkun 2007-2019, s.v.

Radt, S. 2008. Strabons Geographika 7: Buch IX-XIII: Kommentar. Göttingen.

Rausch, S. 2013. Bilder des Nordens: Vorstellungen vom Norden in der griechischen Literatur von Homer bis zum Ende des Hellenismus. Berlin.

Roller, D. W. 2014. The Geography of Strabo. Cambridge.

- 2018a. Cleopatra's Daughters and Other Royal Women of the Augustan Era. Oxford.

- 2018b. A Historical and Topographical Guide to the Geography of Strabo. Cambridge.

Ruscu, L. 2018. "Burebista, König der Geten” (2008, revised 2018), in Coşkun 20072019 s.v.

Saprykin, S. Yu. 1996. Pontijskoe tsarstvo: Gosudarstvo grekov i vararov v Pričernomor'e (The Pontic Realm: A State of Greeks and Barbarians on the Black Sea). Moscow.

- 2002. Bosporskoe tsarstvo na rubezhe dvukh épokh (The Kingdom of Bosporus on the Verge of Two Epochs). Moscow.

Schmitt, R. 1972. "Die achämenidische Satrapie Tayaiy drayahyā," Historia 21: 522-527. 
Sekunda, N. 2019. "The Seleukid Elephant Corps after Apameia," in A. Coşkun and D. Engels (eds.), Rome and the Seleukid East: Selected Papers from Seleukid Study Day V, Brussels, 21-23 Aug. 2015. Brussels. 159-173.

Stein-Kramer, M. 1988. Die Klientelkönigreiche Kleinasiens in der Außenpolitik der späten Republik und des Augustus. Berlin.

Sullivan, R. D. 1980. "Dynasts in Cappadocia," $A N R W$ II 7.2: 1125-68.

- 1990. Near Eastern Royalty and Rome, 100-30 B.C. Toronto.

Talbert, R. J. A. ed. 2000. Map by Map Directory to Accompany Barrington Atlas of the Greek and Roman World. Princeton.

Veh, O. and K. Brodersen. 1987. Appian von Alexandria, Römische Geschichte, Erster Teil: Die römische Reichsbildung. Stuttgart.

von Bredow, I. 2018. "Pharnakes (2)" (2006, consulted 2018), Brill's New Pauly Online.

Yailenko, V. P. 2010. Tysyacheletniy bosporskiy reich: Istoriya i épigrafika Bospora VI v. do n. e. $-V$ v. n.é. (The Thousand-Year Bosporan Kingdom: History and Epigraphy of the Bosporos from the 6 th Cent. B.C. to the 5th Cent. A.D.). Moscow.

Yoshimura, T. 1961. "Die Auxiliartruppen und die Provinzialklientel in der Römischen Republik," Historia 10: 473-495. 